\title{
Exodus of clergy: Responding to, reinterpreting or relinquishing the call
}

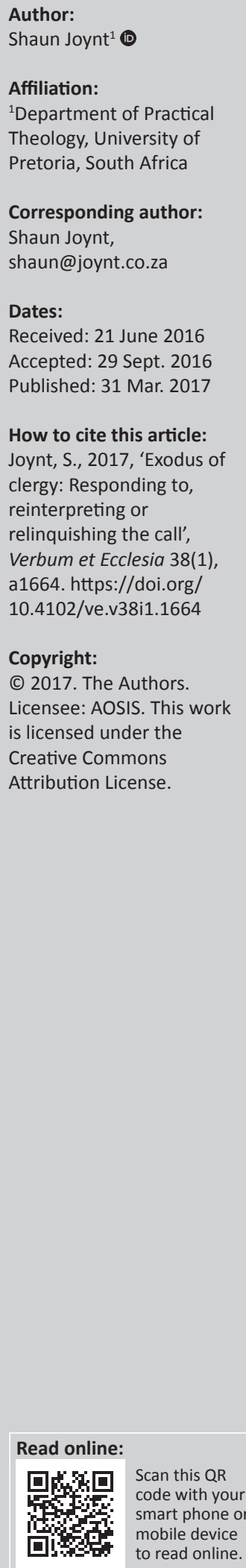

\begin{abstract}
'Who will lead the sheep when the shepherds are gone?' Clergy plays an important role in the establishing and sustaining of the church; without them, congregants will not be rooted in the faith nor will the faith be transmitted to the next generation. The shortage of clergy in the Roman Catholic Church and the distribution or displacement challenge facing the Protestant church pose a risk to the future of the church; therefore, the response of clergy to their call to full-time pastoral ministry is crucial for the continued existence of the church. The purpose of this study was to discover the variables involved in responding to the call to full-time pastoral ministry in a church. A grounded theory approach was used to discover the properties of the core category: 'calling'. Semi-structured interviews were conducted, and data were coded using Glaser and Strauss' grounded theory methodology. The core category 'calling' included properties such as age, defining what a call is or is not; it evolves over time, it has an aspect of timing and it requires 'worldly experience' to be effective. Osmer's descriptive-empirical task was used as a practical theological lens through which to view the core category 'calling'. The results indicated three responses by clergy who had left full-time pastoral ministry: not being called in the first place, a dual call (being bi-vocational) and being called but leaving anyway. Further research is needed to assist clergy in accurately identifying and developing their call to full-time pastoral ministry.

Intradisciplinary and/or interdisciplinary implications: The research calls for an ongoing dialogue with regard to the concept of clergy calling and initiates this by means of a practical theology perspective of a grounded theory study. Future research recommendations are suggested.
\end{abstract}

\section{Introduction}

\section{A shortage of clergy}

The church as an organisation consists of, among other things, clergy and officers who fulfil specific duties (Sykes 1982:166; cf. Heitink 2007:19). They contribute to the growth, both quantitatively and qualitatively, of the church by equipping members in their relationship with God, one another and those outside their community. A shortage of trained clergy negatively affects these outcomes. Factors contributing to the decline in the availability of clergy include the secularisation and duality of vocation, marital and family challenges, conflict and financial issues, and a multitude of others (Hoge \& Wenger 2005:49; cf. Carroll 2006:167-169; see Percy 2006:26-29).

There is a growing shortage of priests in the Roman Catholic Church (Carroll 2006:14, cf. Mohler 2016). Since 1965, the number of priests has declined in contrast to an increasing church membership (McCloskey 2006, see CARA 2015). Seminarian numbers have declined by $90 \%$ (McCloskey 2006, cf. Dunbar 2009:374). The media have taken note of the shortage and its implications, specifically towards the dying that requires last rites (CBS News.com 2010). The shortage is global in nature affecting Africa, USA, Latin America, Europe and China (Mikhail 2006).

The Anglican Church, United Methodists and Assemblies of God have also experienced a shortage of clergy (Milbank 2008:128). Closer to home, the Dutch Reformed Church in South Africa projects a clergy shortage within the next 8 years and currently deploys a number of retired clergy to serve in local congregations (De Villiers 2010:8). In contrast to the Roman Catholic Church, the Protestant church is experiencing more of a distribution or placement challenge (Chaves 2001:36; see Jud et al. 1970:59). There are enough Protestant clergy, yet two reasons for the current placement challenge are inadequate remuneration and the resistance to relocate to an undesirable location (Chaves 2001:36). The resistance to relocate is because of the inability of the clergy's spouse to gain 
meaningful employment in the new, usually smaller or rural, location and the higher salaries required by mid-life or second career clergy rendering them less mobile (Chaves 2001:36-37).

\section{Being called}

Calling can be religious (linked to a faith), vocational (that which a person perceives as his or her purpose in life) or a means to self-exploration and fulfilment (Nillsen et al. 2014:12). Initially, a call was understood to be 'a summons by God to faith and discipleship' (Harvey 2014:29). Later, it was understood to be a 'counter-cultural decision with significant risks' (this occurred during the persecution of the early church and often included martyrdom), then a call to monastic life or the priesthood, then a call to ecclesial ministry (medieval period), until Luther and other reformers stated that a divine calling could be followed no matter what one's occupation (Harvey 2014:29). With the advent of the industrial revolution 'the idea of vocation became increasingly secularised' (Harvey 2014:29). Clergy have not escaped the professionalisation of their occupation which steered the 'focus of the clergy's work from fulfilling a traditional calling to the gaining of results' (Mills 1985:170). Yet at the same time, the sense of calling clergy experience, contributes to higher satisfaction and longevity in their vocation (Nillsen et al. 2014:17). More recently calling has been defined, sociologically, as:

a transcendent summons, experienced as originating beyond the self, to approach a particular life role in a manner oriented toward demonstrating or deriving a sense of purpose or meaningfulness and that holds other-oriented values and goals as primary sources of motivation. (Dik \& Duffy 2009:34)

Two of the aspects affecting clergy retention are role and vocational commitment. Role commitment is 'a process which links a person to a position in a social system to the extent that the position provides him a favorable net balance rewards over costs' (Schoenherr \& Greely 1974:407). Vocational commitment is affected by denomination (the degree of support received), economics (to a small degree), the local congregation (issues such as staff conflict and ineffective communication affect it negatively), familial factors (a large influence, specifically linked to the spouse), personal fulfilment and theology, and age and education (younger and more educated clergy experience greater dissatisfaction) (Hoge, Dyble \& Polk 1981:133). Personal fulfilment is the greatest contributing factor to the role commitment which facilitates clergy remaining in their present pastorate (Hoge et al. 1981:145). Chang (2004:22) lists the main reasons for clergy leaving for secular work as the discouragement and depression linked to their lives and ministries.

\section{Roles and responsibilities}

Responding to the call also requires 'counting the cost' which includes making an informed decision based on clergy roles, responsibilities and expectations. Blizzard (1956:508) describes six practitioner roles of a parish minister, which are behaviourally oriented as administrator, organiser, pastor, preacher, priest and teacher. These have expanded in scope and include contemporary variations such as life coach. Expectations are broad and sometimes unrealistic (Barna 1993:52) which lead to the question London and Wiseman (1993:57) pose: who decides what pastors do? Niebuhr, Williams and Gustafson (1956) indicate that the function of the minister in the modern community is undefined.

\section{Research method and design}

The aim of this article is a focus on the core category 'calling' which has been identified as one of the reasons clergy leave full-time pastoral ministry in the church as an organisation. This core category emerged after conducting a grounded theory study.

Grounded theory was selected as the research methodology for this study because it best suited the research question. It provides for intuitive appeal, fosters creativity, has the potential to conceptualise, provides a systematic approach to data analysis and provides for data depth and richness (Hussein et al. 2014:35). It has been used widely across many disciplines and subject areas and is a systematically comparative inductive approach to gather data and build theory (Charmaz 2014:328; Bryant \& Charmaz 2007:1). Data are collected (by means of interviews), coded (by hand, using software, or a combination of both) and compared in cyclical patterns until categories and their properties are identified. This process continues until theoretical saturation has been achieved (no new codes or categories emerge) and is completed with the construction of a substantive grounded theory.

The study was conducted with participants at a church-based training institution located in Pretoria, South Africa. Participants in this study refer specifically to the:

men and women who have commenced theological studies at an undergraduate level through the Hatfield Training Centre, have been employed full time in a pastoral capacity by a church and have subsequently left. Research [was] conducted involving graduates of the BA degree programme offered by the Hatfield Training Centre of the Hatfield Christian Church in Pretoria from 1990 onwards. (Joynt 2013:33)

Permission was obtained to access records with the purpose of selecting participants who were eligible according to the three pre-determined criteria mentioned above. Records of 188 potential participants, dating back to 1989 , were supplied. In many instances, the records were incomplete or out-ofdate thus reducing the potential sample size. Searching on Facebook (a social media platform) resulted in finding 50 eligible participants (43 males and 7 females) of which 15 did not respond. Of the 35 that responded, 13 met the criteria and 8 were interviewed in person while 2 were interviewed telephonically due to distance constraints. In total, 13 semistructured interviews were conducted in three cycles with 10 participants. Participant 1, 3 and 7 were interviewed a second time to seek theoretical saturation (interviews 8,9 and 10 
respectively). All 10 were male as very few females responded, and the females who had, did not meet the research criteria. The age of the 10 participants when leaving full-time pastoral ministry ranged between 20 and 57 years. The identity of participants was kept confidential.

One-on-one interviews were conducted in venues that facilitated a relaxed atmosphere conducive for talking freely. Interviews ranged between 40 and 90 min each. At the beginning of the interview, participants were reminded of the reason for the study, the procedure of the interview (which would include note taking and digital recording), the risks involved (minimal, if any), the benefits involved (contribution to research), the right to leave without any negative consequences, and confidentiality. ${ }^{1}$ Semi-structured interviews consisting of five open-ended questions were conducted with the view of understanding the entry into, time within and subsequent leaving of full-time pastoral ministry in a church. Recorded interviews were transcribed and then coded using software. Often multiple codes were created from a single line or sentence. The codes were grouped into clusters sharing the same properties, namely categories. These categories were used to construct a theory that describes the concept of responding to the call. The theory consists of six steps in responding to the call: preparation, growth, 'fitting into', defending, conflict and leaving. The main category of calling is the subject of this article.

A researcher's research position assists in understanding his or her research approach. This researcher's social location may be succinctly described as:

a social/critical realism research paradigm, a depth realist ontology (reality consists in three domains: empirical, actual, and real), a neo-realist epistemology, a grounded theory methodology, using interviews as a method, with an abductive reasoning strategy. (Joynt 2013:59)

\section{Results}

Coding 13 interviews resulted in 235 codes which were clustered into 12 categories. The category 'calling' ranked first with a total of 89 codes. The cluster of codes related to calling was diverse and comprised of various properties such as age, defining what a call is or is not, that it evolves over time, it has an aspect of timing, and it requires 'worldly experience' for one to be effective.

\section{The call and age}

Most participants responded to what they deemed a call to full-time pastoral ministry in their late teens and twenties.

\section{Interview 7:}

... towards the end of my 19th year age I came aboard as a student pastor. (Participant 7, male, 37 years)

\section{Interview 11:}

Because um when you are young you have no clue about what is going on in the world and people's lives, you want to minister to

1.These were provided either via email before the interview or onsite. all these married people and you haven't even been married for six months but you feel you gonna help them .... (Participant 8 , male, 41 years)

\section{The call evolves over time}

Participants considered their call to have evolved over time, whether it was being called into full-time pastoral ministry, a change of direction in the call, realising one is not called to full-time pastoral ministry, or using full-time pastoral ministry as a stepping stone to another call.

\section{Interview 5:}

... a calling that emerged out of youth work. (Participant 5, male, 43 years)

Interview 6:

... I knew it would be a time of full time ministry. Whether that was as a missionary or pastor, I wasn't sure. (Participant 6, male, 40 years)

Interview 3:

There was no mid-life crisis or anything. [...] We had kind of expected it [a pastoral call] and kind of not expecting it. Not knowing what would happen. (Participant 3, male, 76 years)

Three concepts closely linked to experiencing the call as an evolving process emerged: (1) a change in direction of the call, (2) not being called to full-time pastoral ministry and (3) using the pastorate as a stepping stone to what is believed to be the actual call.

A change in direction of the call from full-time pastoral ministry to something else.

\section{Interview 2:}

... The doors started shutting down in terms of ministry and the desire to enter into the business world became stronger and stronger. (Participant 2, male, 27 years)

Interview 4:

That is where the seed got planted in me [for missions] so when I got back from .... (Participant 4, male, 40 years)

\section{Interview 5:}

I started to feel an increasing call, um, to mission as opposed to pastoral work. (Participant 5, male, 43 years)

Not being called to full-time pastoral ministry even though preparing for it.

\section{Interview 2:}

[S]o it was the first thing like I felt I wasn't called to this type of ministry. When I was doing my last year of theology and I said to Pastor XXX, I said, Pastor XXX, I, I'm not, I don't feel like I'm called to be a pastor [...] I don't think that's what God has for me. (Participant 2, male, 27 years) 
Interview 4:

I don't want to be a pastor, you know, it's not, my heart was always missions .... (Participant 4, male, 40 years)

\section{Interview 6:}

$[N]$ ot necessarily as a pastor. I just knew, no I didn't have any idea of exactly what form that would take [...] because I don't feel I'm called as a pastor. (Participant 6, male, 40 years)

Some respondents used the pastorate as a stepping stone to what is believed to be their actual call.

\section{Interview 13:}

I was very clear of my calling. I was called to, to, to well what I understood at that point of time was as a missionary. Um but I also knew ... that I was going to go for a season into pastoral work and from there uh into missions ... (Participant 10, male, 44 years)

\section{Interview 4:}

So then I thought ok well I have got to find myself a local church and get involved in a local church; that they can trust me and then send me out to the mission field. (Participant 4, male, 40 years)

\section{The call and preparing for it}

Participants equated answering the call to preparing at a Bible college and becoming a pastor.

\section{Interview 2:}

I was studying theology so the logical outcome of the, of the theological studies would be to, would be to be a pastor or to be involved in full time ministry. (Participant 2, male, 27 years)

\section{Interview 4:}

Because all those types of Christian books, I grabbed those and I ate them up because you know, I was passionate for the Lord and the things of the Lord and all those guys, they came out of drugs or whatever, they got saved, they went to Bible School and they went into a life of ministry. So I thought well that is what I want to do. (Participant 4 , male, 40 years)

\section{Interview 5:}

It was the only thing I knew and the only model I knew. [going to Bible College and entering pastoral ministry]. (Participant 5, male, 43 years)

\section{Interview 6:}

I was still young, I was still at school when I gave my life to the Lord as I mean, up to finishing Matric [Grade 12], and sort of, where to from here. And, just people recommended Bible College. (Participant 6, male, 40 years)

\section{The call and timing}

Some participants indicated that there is a timing aspect to the call - when to respond to it.

\section{Interview 12:}

$[P]$ robably the biggest thing for me is, is that God has a call on your life and that His timing is perfect [...] That you are called and that you need to do what your hand can find to do, you know. Until that calling comes along God will open that door when the time is right, even if it is 10 years [later]. (Participant 9, male, 38 years)

\section{The call and prior 'worldly experience'}

Participants also stated that 'worldly exposure or experience' (what they considered 'real-life' experience) is a necessity for answering the call to full-time pastoral ministry.

\section{Interview 12:}

[I] think timing was probably an issue you know. I realized that my time in the world was actually where training for the ministry happened. You know a book doesn't tell you, teach you how to work with people [...] My opinion is that people that grow up in the church ... [have] no reality of what, you work, you ministering to people who are out in the world, who have to work every day and yet you cannot relate to them at all. The stresses they go through, now I know exactly what they are going through etc. ... You know that you do have a secular job and a bit in the ministry because there is just something about being in contact with the real world. That your skills get refined, that you really start to learn how to work with people. (Participant 9, male, 38 years)

Interview 11:

So um, those were, those were things that opened my eyes that God um, took me out of the ministry, into the world and you started to grow in terms of your ministry understanding people and uh you, you were able to minister to people in a deeper more effective way. (Participant 8 , male, 41 years)

\section{Interview 13:}

I think one when you go through Bible College you have sort of an academic idea and when you are in a local church you see what's happening and things. But you don't really know um, until you learn experientially what it means to shepherd a flock ... (Participant 10, male, 44 years)

\section{Discussion}

Joynt (2013:217) states that clergy respond to a call. Other professions may term this a response to a vocation. For clergy, a call involves among others, a spiritual aspect which is demonstrated in service to God and the faith community within the structure or organisation of the church. Responding to this call requires spiritual formation, theological preparation and dealing with experiences that either validate or challenge the call.

The following were findings from the interviews:

- Not all clergy have a deep sense of calling to full-time pastoral ministry yet often function within this position;

- The rationale for clergy doing so is that it is only for a season or a stepping stone to something else (either business or missions);

- Preparation for full-time pastoral ministry is usually within a formal setting such as a Bible college or seminary;

- This preparation is considered by ex-clergy to be insufficient for the scenarios they were to face in full-time pastoral ministry; 
- The call is an evolving process whereby the call is identified, sometimes adjusted, the cost considered, and sometimes a change in direction taking place (to either business or missions);

- Prior worldly experience is regarded as conducive to understanding congregants' situations;

- $\quad$ Proper timing in being released into full-time pastoral ministry is seen in a positive light while a premature release has been observed by ex-clergy to have an adverse effect. (Joynt 2013:217)

\section{A practical theological perspective}

A practical theological perspective was used to further explore the findings. Practical theology is 'the term for a theological discipline that has church activities as its theme' (Dietrich 2005:315). Hermans (2004:25) states that practical theology studies three practices: the action of the pastor, the practices of the church, and the 'practices within the coordinates of the church, Christianity and society as a whole'. This article focuses on the action of the pastor in responding to the call to full-time pastoral ministry within a church.

According to Osmer and Schweitzer (2003:1), there are four tasks in contemporary practical theology: the descriptiveempirical, the interpretive, the normative, and the pragmatic. Firstly, the descriptive-empirical task asks what is going on and tries to 'describe as fully and as accurately as possible a particular field of experience' (Osmer \& Schweitzer 2003:2). The data indicated that clergy who left full-time pastoral ministry respond to a call in the following three ways: realising that they are not called, that they have a dual or bi-vocational call, or that they are called but are unable to continue therein.

Secondly, the interpretive task asks why is this going on as the 'findings of more focused research are located in a framework that provides an explanation of patterns of behaviour, attitudes, and ideas' (Osmer \& Schweitzer 2003:3). A cycle of description-interpretation-descriptioninterpretation takes place during the interpretive task which strongly correlates with abductive reasoning (Osmer \& Schweitzer 2003:3). It was observed that participants in the study left full-time pastoral ministry because: (1) they came to the conclusion that they were not called in the first place, (2) they were called to be pastors and missionaries or pastors and businessmen at the same time or seasonally (one following the other) and (3) they were called but left because of leadership challenges from their senior pastor, congregation or denomination.

Thirdly, the normative task asks what ought to be going on or 'what forms ought religious praxis take in this particular social context?' which means it 'focuses on the construction of theological and ethical norms by which to critically assess, guide, and reform some dimension of contemporary religious praxis' (Osmer \& Schweitzer 2003:3). These norms are strongly context-dependent, taking into account the particularities of a specific context (Osmer \& Schweitzer
2003:3). Clergy who are called to full-time pastoral ministry need to be guided in discovering, nurturing and confirming their call (Sizemore 2014:3). This ought to include, among others: (1) confirmation of being called (being confirmed by self, family, friends, colleagues, congregation, denomination), (2) personality assessments, (3) appropriate levels of education and skills including resiliency training (Elkington 2013:11), (4) collegial, congregational and denominational support and (5) an apprentice model that 'trains and tests' the candidates before they are released on their own.

Fourthly, and finally, the pragmatic task asks how might we respond or how might this area of praxis be shaped to embody more fully the normative commitments of a religious tradition in this particular context of experience?' (Osmer \& Schweitzer 2003:4). It 'focuses on the development of rules of art ... [which] are open-ended guidelines that can assist those who are leading or participating in a particular form of praxis' (Osmer \& Schweitzer 2003:4). Developing a comprehensive yet not necessarily exhaustive process of discovering and developing the call to full-time pastoral ministry is needed. Based on the findings of this study, this process might include: (1) communicating that becoming full-time pastoral clergy is not the only way to serve God, (2) highlighting the challenge of a dualistic worldview that differentiates between the sacred and the secular, (3) assisting those who are struggling to determine if they are called to full-time pastoral ministry and (4) actively addressing the hindrances to remaining in full-time pastoral ministry - this will be the subject of future papers.

\section{Conclusion}

Clergy play an important role in the church. A shortage of clergy has a negative impact on the numerical and spiritual growth of the church as an organisation. The study identified variables that contribute to a shortage of clergy. The category 'calling' comprised the most codes. Clergy respond to a call to function (minister) within the church. They respond to the call to full-time pastoral ministry in different ways. Some respond to the call yet leave for various reasons; some consider the call to be seasonal (e.g. a set time frame) or bi-vocational in nature (e.g. both pastoral and business or both pastoral and missions); and some were never called in the first place but merely followed the only route they considered to be a means to serve God. Within the study participants indicated that they were called (Participants 1, 7, 8 and 9), had a dual call (pastoral and something else, such as business or missions, Participants 2, 6 and 10), or they were not called ('only for a season', Participants 6 and 10 or using it as a 'stepping stone', Participants 4 and 10). Formal education was deemed insufficient for dealing with real-life scenarios, while a delayed entry into full-time pastoral ministry meant participants had obtained 'worldly experience' which equated to preparation for real-life scenarios.

The value of the study is that it has identified the category 'calling' as one of the reasons why clergy leave full-time pastoral ministry within a Charismatic megachurch setting located in 
South Africa. The findings correspond to studies conducted in the USA (see Hoge and Wenger 2005). Limitations of this study included: sourcing participants that met the required criteria, the use of non-research specific software (Microsoft Excel) as opposed to ATLAS.ti or NVivo, and very limited access to congregational and denominational statistics and surveys. Additional limitations include: a specific time period (19902010); clergy who attained a Bachelor of Arts degree from Global University (previously known as ICI University) as offered by the Hatfield Training Centre located in Pretoria, South Africa; clergy employed in full-time pastoral ministry at a church; and clergy within the sample group residing in South Africa. The study was not representative or inclusive of all denominations within South Africa, nor representative or inclusive of all theological training institutions within South Africa, nor did it determine or evaluate the preparation and training of clergy within the selected theological training institution, namely the Hatfield Training Centre.

Future research in the area of clergy called to full-time pastoral ministry might include a comparative study on the aspect of 'calling' within the different faith traditions, noting their successes as well as their shortcomings, thereafter constructing a composite model that may serve future generations by providing 'shepherds for the sheep' who remain in the church. Future research may also include exploring contemporary challenges clergy face in the area of roles and responsibilities and how they could best be prepared for these, for example, an increased focus on apprenticeship.

\section{Acknowledgements}

Thank you to the clergy who were willing to talk about their journey into, through and out of full-time pastoral ministry. Thank you to Prof. Yolanda Dreyer and the University of Pretoria for both the opportunity and resources to conduct this research. Thank you to Prof. Eleanor Lemmer for the critical reading of the first draft. This article is based on a conference paper of the same title presented at the Athens Institute for Education and Research's Annual International Symposium on Religion \& Theology held on 27-30 June 2016 in Athens, Greece. Both the conference paper and subsequent article focus on one of the core categories of the author's PhD dissertation (University of Pretoria, Dec 2012 - supervised by Prof. Dr Yolanda Dreyer). It is the second in a proposed series of papers and articles focusing on different categories comprising the reasons, as discovered through a grounded theory exploration, why clergy leave full-time pastoral ministry at a church.

\section{Competing interests}

The author declares that he has no financial or personal relationships that may have inappropriately influenced him in writing this article.

\section{References}

Barna, G., 1993, Today's pastors: A revealing look at what pastors are saying about themselves, their peers, and the pressures they face, Regal Books, Ventura, CA. Blizzard, S.W., 1956, 'The Minister's Dilemma', The Christian Century 73(1), 508-510.
Bryant, A. \& Charmaz, K., 2007, 'Grounded theory research: Methods \& practices', in A. Bryant \& K. Charmaz (eds.), Grounded theory, pp. 1-28, Sage, London.

CARA, 2015, Frequently requested church statistics, Washington, viewed 17 June 2016, from http://cara.georgetown.edu/frequently-requested-church-statistics/

Carroll, J.W., 2006, God's potters: Pastoral leadership and the shaping of congregations, William B. Eerdmans, Grand Rapids, MI.

CBS News.com, 2010, Priest shortage hurts faithful on sickbeds, CBS Corporation News, New York, viewed 17 June 2016, from http://www.cbsnews.com/ stories/2010/01/27/health/main6147472.shtml

Chang, P.M.Y., 2004, Assessing the clergy supply in the 21st century, Duke Divinity School, Durham, NC, viewed 17 June 2016, from http://pulpitandpew.org/ assessing-clergy-supply-21st-century

Charmaz, K., 2014, Constructing grounded theory, 2nd edn., Sage, London.

Chaves, M., 2001, 'Challenges for the 21st century', The Journal of the Interim Ministry Network, 2001 Annual Review December, 27-39.

De Villiers, J., 2010, Talle NG kuddes herderloos: ' $n$ Voltydse predikant per gemeente kan binnekort 'n luukse wees, Rapport. 13 Sep., p. 8a, viewed 17 June 2016, from http://www.rapport.co.za/Suid-Afrika/Nuus/Talle-NG-kuddes-herderloos20100612

Dietrich, R., 2005, 'Practical theology: Development in protestant Germany', in The encyclopaedia of Christianity: Vol 4, P-Sh, pp. 375-404, Wm. B. Eerdmans, Grand Rapids, MI.

Dik, B. and Duffy, R., 2009, 'Calling and vocation at work', The Counselling Psychologist 37(3), 424-450. https://doi.org/10.1177/0011000008316430

Dunbar, B., 2009, Out of the jungle, 6th edn., RoseDog Books, Pittsburgh, PA.

Elkington, R., 2013, 'Adversity in pastoral leadership: Are pastors leaving the ministry in record numbers, and if so, why?', Verbum et Ecclesia 34(1), Art. \#821, 1-13. https://doi.org/10.4102/ve.v34i1.821

Harvey, M., 2014, 'Exploring the concepts of call and vocation in an Australian Anglican context', St Mark's Review: Theology in New Spaces (229), 3.

Heitink, G., 2007, Een kerk met karakter: Tijd voor heroriëntatie, Uitgeverij Kok Kampen, Utrecht, Netherlands.

Hermans, C.A.M., 2004, "When theology goes "practical": From applied to practical theology', in C.A.M. Hermans \& M.E. Moore (eds.), Hermeneutics and empirical research in practical theology: The contribution of empirical theology by Johannes A. van der Ven, pp. 21-51, Koninklijke Brill NV, Leiden, Netherlands.

Hoge, D.R. \& Wenger, J.E., 2005, Pastors in transition: Why clergy leave local church ministry, Wm. B. Eerdmans, Grand Rapids, MI.

Hoge, R., Dyble, J.E. \& Polk, D.T., 1981, 'Organizational and situational influences on vocational commitment of protestant ministers', Review of Religious Research 23(2), 133-149, viewed 17 June 2016, from http://www.jstor.org/stable/3511924

Hussein, M.E., Hirst, S., Salyers, V. \& Osuji, J., 2014, 'Using grounded theory as a method of inquiry: Advantages and disadvantages', The Qualitative Report 19, 1-15, viewed 29 May 2016, from http://www.nova.edu/ssss/QR/QR19/el$1-15$, viewed
hussein13.pdf

Joynt, S., 2013, Exodus of clergy: A practical theological grounded theory exploration, Unpublished manuscript, University of Pretoria, Pretoria, South Africa.

Jud, G.J., Mills, E.W., Jr. \& Burch, G., 1970, Ex-pastors, Pilgrim, Boston, MA

London, H.B., Jr. \& Wiseman, N.B., 1993, Pastors at risk: Help for pastors, hope for the church, Victor Books, Wheaton, IL.

McCloskey, J., 2006, State of US Catholic Church at beginning of 2006, Spero News, Houston, TX, viewed 18 March 2010, from http://www.speroforum.com/site/ article.asp?idCategory=34\&idsub=127\&id $=2427$

Milbank, J., 2008, 'Stale expressions: The management-shaped church', Studies in Christian Ethics 21(1), 117-128. https://doi.org/10.1177/0953946808089730

Mikhail, D., 2006, Pope Benedict's indifference and Africa's faith, Open Democracy, London, viewed 17 June 2016, from http://www.opendemocracy.net/faithaboutfaith/pope-benedict_3195.jsp

Mills, E.W., 1985, 'The sacred in ministry studies', in P.E. Hammond (ed.), The sacred in a secular age, pp. 167-183, University of California Press, Los Angeles, CA.

Mohler, A., 2016, The Briefing 05-19-16, viewed 28 May 2016, from http://www. albertmohler.com/2016/05/19/the-briefing-05-19-16/

Niebuhr, H.R., Williams, D.D. \& Gustafson, J.M., 1956, The purpose of the Church and its ministry, viewed 17 June 2016, from http://www.religion-online.org/ showchapter.asp?title $=407 \& C=152$

Nillsen, C., Earl, J.K., Elizondo, F. \& Wadlington, P.L., 2014, 'Do birds of a feather flock together? An examination of calling, congruence, job design and personality as
predictors of job satisfaction and tenure', Journal of Beliefs \& Values 35(1), 10-24. predictors of job satisfaction and tenure', Journal
https://doi.org/10.1080/13617672.2014.884845

Osmer, R.R. \& Schweitzer, F.L., 2003, Developing a public faith: New directions in practical theology, Chalice, St. Louis, MI.

Percy, M., 2006, Clergy: The origin of species, The Continuum International Publishing Group, London.

Schoenherr, R.A. \& Greeley, A.M., 1974, 'Role commitment processes and the American Catholic priesthood', American Sociological Review 39(3), 407-426. https://doi.org/10.2307/2094298

Sizemore, R.A., 2014, Calling, affinity, and personal growth: Key factors in long term ministries, Unpublished manuscript, Trinity Evangelical Divinity School, Deerfield, IL.

Sykes, J.B., 1982, The concise oxford dictionary of current English, Clarendon, Oxford. 